\title{
Sobre lo infame: de lo inmundo del Arte y su enfermedad diogénica
}

\section{About infamy: the filthiness of Art and its diogenic disease}

\author{
Miguel Ranilla-RodríGuez \\ FInstituto de Enseñanza Secundaria Albanta. Fuenlabrada. Madrid. \\ miguelranillarodriguez@gmail.com
}

Recibido: 26 de abril de 2014

Aprobado: 15 de noviembre de 2014

\section{Resumen}

En el presente artículo, postularemos la relación directa que existe entre la producción de basura y la de objetos artísticos; su sistema de manufactura, consumo y posterior deshecho. Surge en esta relación entonces, un personaje de interés que nos servirá como referencia para cotejar su modus operandi con el lugar de los artistas y las artes en este mundo enfermo, el Diógenes. El obseso que vive entre basura. El absurdo de la conquista del infinito de la ilógica dentro de una lógica. La cantidad nubla y ciega, nada se disfruta, nada se aprecia; lo incontable abandona su lugar en la memoria-memorable- y solo existe acumulación patológica, montañas de basura, deseos de aferrarse a la fe vital de la creencia de estar haciendo Algo por sí mismos. Hacer por hacer y construir castillos de arena, acumulación, detritus y polvo. Una nueva lógica nace, por el disfrute, por la enfermedad y lo vacío, la destrucción en un mundo sin historia. «Artistas del mundo, ¡abandonad! ¡No tenéis nada que perder más que vuestras profesiones!» (Kaprow, 2007, p. 37).

Palabras clave: artes plásticas, acumulación, símbolo, nadería.

Ranilla-Rodríguez, M. (2015): Sobre lo infame: de lo inmundo del Arte y su enfermedad diogénica. Arte, Individuo y Sociedad, 27(2) 279-294

\begin{abstract}
In this paper, we postulate the direct relationship that exists between waste production and artistic objects; its manufacturing system, consumption, and subsequent waste. What arises in this relationship then, is another character of interest -and that will serve as a reference to compare its modus operandi with the place of artists and the arts-, in this sick world, the Diogenes. The obsessed that lives among the garbage. The absurdity of the conquest of the infinite of the illogical within the logical. The amount clouded and blinded, nothing is enjoyed, nothing is appreciated; the countless abandons its place in the memory -memorable- and there only exists a pathological accumulation, mountains of garbage, desires to hold on to vital faith of the belief of doing Something for themselves. Working just to work and building something that will not last, like a sand castle, accumulation of detritus and dust. A new logic is born, the enjoyment of diseases and emptiness, the destruction of a world without a history. "Artists of the world, abandon! You have nothing to lose but your own professions!» (Kaprow, 2007, p. 37).
\end{abstract}

Keywords: visual arts, build symbol, trifle.

Sumario: 1. Introducción, 2. Estado de la cuestión en el sistema de los objetos respecto del arte, 3. La patología de la acumulación y la inmundicia, 4. Conclusiones. Referencias. 


\section{Introducción}

\section{Panorama de las Artes Plásticas}

(...) la ceguera frente al mamoneo (...) ¿Cuántas veces no habremos escuchado preguntas retóricas en torno a sandeces pretendidamente sublimes? ¿Quién no ha sospechado que detrás de elogios ditirámbicos se oculta el descarado amiguismo? ¿No canta demasiado la pomada administrada a destajo, en un país de clientelismo endémico? Saturados de patetismo (...) intentamos encontrar una "redención artística" que, finalmente, no supone más que la participación de otro gran guiñol (Castro, F. 2012, p. 185).

Las artes plásticas en su contemporaneidad muestran su cara más lamentable y han encontrado el atroz refugio en lugares tan inhóspitos y grises como galerías, museos, centros culturales, etc. que aceptan a cualquier mequetrefe y sus pretensiones con tal de no contar nada de Interés y de hacer toda esta pantomima más llevadera. Templos de lo nimio -«...el turbio lugar en que el museo de arte «moderno» se ha convertido» (Clair, 2007, p. 33)-, en dónde nada se dice porque nada se tiene que decir. «Las artes modernas se han convertido en un comentario en sí mismas» (Kaprow, 2007, p. 35). El único anhelo del artista del hoy, ser reconocido, adquirir el capital social pertinente que permita la aceptación del artista en el gremio de las artes.

(...) Pantomima de enteradillos. Su única audiencia es la que corresponde al listado de profesiones creativas que se contemplan narcisistamente a sí mismas, representando un combate entre sacerdotes autoproclamados y toda una retahila de rebeldes, bromistas, golfillos y agentes triples que parecen estar intentando destruir su iglesia(...) Rezando por ellos mismos y su religión (Kaprow, A. 2007, p. 37).

Artistas que forman corrillos de patio de colegio debatiendo los aspectos más reiterados de una filosofía creativa en decadencia, y que después producen una masa de objetos llamados artísticos que son de una factura más que discutible. Basura. Un arte, plagado de pensadores de segunda división de propuestas creativas infantiloides que bien, por una estética adecuada a un momento del mercado, por méritos del amiguismo o por el tesón de un cabestro golpeando su cabeza contra un muro de barro, consigue abrir una brecha y asomar la cabeza para ver el paraíso del ángel caído y de la manzana podrida en el paraíso de la consagración. Decir Arte hoy en día, es no decir nada sustancial. En pocas palabras, el arte, nos ha abandonado y por despecho, le escupimos a la cara.

\section{Panorama de los artistas}

Sin duda, la culpabilidad del artista es la falta de creatividad. La sobreinformación y los principios prioritarios de la sociedad, hedonista y narcisista que han avasallado el grado altruista de la concepción del arte. La razón a superado a la sinrazón en la lógica de un mundo absurdo. Las escuelas de artes europeas se adaptan poco a poco al sistema privado de enseñanza americano a golpe de dólar y promueven la educación-express. Los estudiantes de artes deambulan por las facultades, futuros 
artistas solitarios con un Macintosh lanzando rayos interestelares e interconectados por chats celulares con terceras personas. El tesón de sentirse individuo aboca a la ansiedad de llegar a ser a cualquier precio. Bien es cierto que aún, en las fábricas de creación de artistas como son las facultades relacionadas con las artes, son capaces de vender el producto idílico de que el arte, aún necesita de artistas. Los pobres futuros artistas, engañados, aún piensan en el futuro de su creatividad, aquella que nunca le enseñaron y que finalmente decide las carencias que hoy se observan en el arte. De esta forma, los artistas, no entienden de creación sino de cómo funciona la sociedad, esto, hace que su determinación no se fundamente en crear, más bien en encontrar un lugar. «Los artistas (...) su deseo está frustrado por una profesión que carece de utilidad inherente» (Kaprow. 2007, p.67). Esto ha significado que los márgenes de las estrategias del arte son perfectamente definibles y que la repetición temática es sistemática. Ya Kaprow (2007) establece una diferenciación entre los grupos/estrategias de artistas y sus manera de trabajar:

Los modelos de situación (espacios públicos ideas y costumbres, con frecuencia preestablecidos). Modelos operacionales (cómo funcionan y qué producen las costumbres y los objetos), modelos estructurales (ciclos naturales, ecologías, y la forma de las cosas, lugares y asuntos), modelos auto-referenciales, o de retroalimentación (cosas o sucesos que se reflejan o "hablan» de si mismos) y modelos de aprendizaje-alegoría de investigación, filosófica, rituales de entrenamiento de la sensibilidad y demostraciones educativas- (p.72- 73).

En síntesis, podemos observar como líneas de trabajo de hoy en día en el arte, oscilan entre el conceptualismo manido y «clásico», lo grosero y lo infantiloide, lo protesta social de marketing, las urdimbres de teorías estéticas-estandarte y el mal de archivo, todas ellas desembocan en soluciones aparentemente distintas pero siempre con el mismo efecto: la nadería. La posmodernidad ha dado paso a la demolición:

El atentado colosal del World Trade Center es el acontecimiento que marca el comienzo del siglo XXI. Tardaremos en salir del estupor ante la gran demolición y, por supuesto, todavía tendremos que acompañar al pensamiento y a la esperanza en su caída en el oscuro agujero, en ese solar desnudo, donde los cimientos son ya espectrales (...) es la obra de arte total. (Castro, 2012, p.185).

Hoy, es el momento para la coctelera en que los artistas vivan el dulce declive, el fracaso de las personalidades y crisol de estereotipos, del mejunje ideológico y el fracaso de la creatividad. El «hipster-conceptualita» ha colonizado lo imbécil. «Los freaks han tomado el mando de las operaciones» (Castro, 2012, p. 38). 


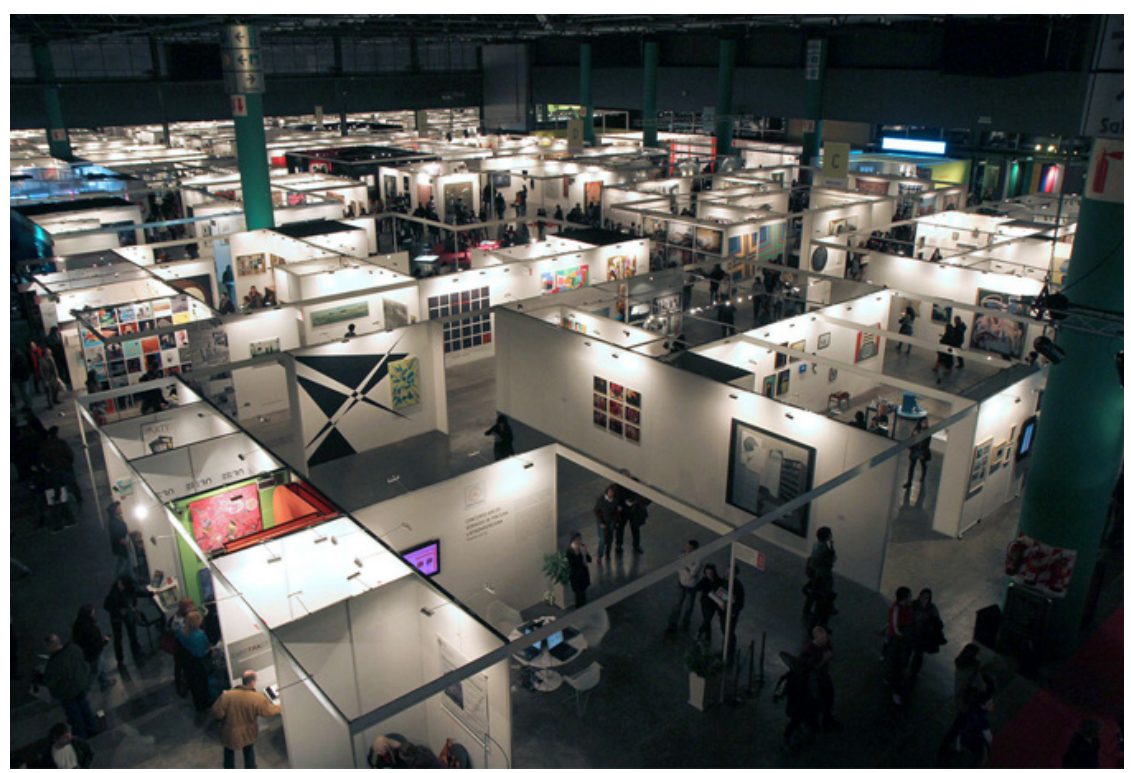

Figura 1. Panorámica de la feria de arte ArteBA, celebrada en el barrio de Palermo en Buenos Aires, Argentina (2013). Recuperada de http://www.unagroupie.com/en-mayo-arteba/

\section{Panorama de la creatividad en las Artes}

La reinterpretación y el plagio son el leit motiv del arte actual, su base radica principalmente en la filosofía y sociología francesa; son todos esos objetos insuflados de contenido de títulos sugerentes, los microrrelatos en las metanarrativas, los obscenos que retozan en lo escatológico, los que sufren del síndrome de Peter pan y mezclan el diseño, el cómic y el grafiti, los escultores del objeto o los que hacen un objetos con otros, los performers que hacen de su vida un teatrillo, los videoartistas que inhalan del cine de la nouvelle vague, de la publicidad y del videoclip, los pintores que redicen lo que ya se ha pintado o los que no encuentran su lugar y mezclan todo estilo que se precie, y de los instaladores que decoran lugares o no-lugares, amén de los que usan pretextos amarillistas «trasnochados» como la sexualidad, la igualdad, la injusticia, etc. o como último recurso, reflexionando como siempre sobre el hecho creativo y artístico, aunque indirectamente degradándolo a cenizas e insultando a la inteligencia.

(...) el arte consiste en (...) dejar siempre abierta o acaso un poco indecisa la vía del sentido, escapando del dogmatismo tanto como de la insignificancia. Actualmente el plegamiento conceptualista, los juegos de alusiones, las complicidades metalingüisticas, son defendidos por la institución museística con verdadera pasión (Castro, F. 2012, p. 9).

Eso sí, a la hora de realizar el hecho artístico por muy fútil que sea, la seriedad y la confianza ha de ser la de aparentar ser plena, esto da seguridad en su «alterego», ¡vade retro! Beuys, decía: todos somos artistas (Otero, 2008), en fin. Sus estrategias creativas, llenas de matices, apuntan a lo homogéneo y por el contrario, 
no precisamente a lo heterodoxo y en dónde es fácil que te pillen copiando. Es tan sencillo duplicar el arte como a los artistas que lo producen. El artista, bajo el síndrome de Peter Pan, inmiscuido en la lucha de una sociedad remota, como en El Señor de las moscas de John Golding. «Una infancia del arte, acaso, bañándose en sus pañales sucios» (Clair. 2007, p. 26).

(...) la infantilización del arte actual no sólo porque amenaza con trivializar todo un espacio cultural en el que debería primar la reflexión, el análisis y la madurez creativa, sino porque forma parte de una puerilización general de la sociedad que apunta a un futuro bastante negro: los ciudadanos van perdiendo capacidad para responsabilizarse de reclamar derechos y cumplir deberes. Frente a la supuesta rebeldía del mundo juvenil, se revela su conformismo, su sometimiento a los dictados de los productores para el consumo (Vozmediano, 2009).

No menos importantes son las palabras que conforman el argot del artista y los temas que trata (redunda), satélites que giran en torno al planeta perdido. Palabrotas como, transversal, sostenible, interconexión en red, protesta, rizoma, inefable, otredad, inherencia... y temas como, el cuerpo, la memoria, la falta, la huella, identidad -de quién sea-, lo fantasmagórico, el no lugar y la territorialización, arte urbano -más bien callejero-, grotesco y repugnante, la relaciones de poder y la protesta laxa, la tecnocracia y los rayos láser, lo freak, el feminismo, el individualismo y yo mismo,... incluso los outsiders que declaran incluso afirmar cierta acritud y negación a la pertenencia directa grupal artística, alegando la frasecilla cadenciosa: yo hago mis cosas sin tener en cuenta al resto; normalmente, o mejor dicho, casi seguro son el clásico patrón de pro-artista fracasado y que en su afán por intentar ser alguien incluso en el depravado y triste mundo del arte actual, se dan cuenta que tal es su frustración, que ni siquiera llegan al grado del mismo. Cabe mencionar el relato de Honore de Balzac, La obra maestra desconocida (2011), en donde el maestro Frenhofer confronta su ineficiencia como artista en una digresión con el mundo; empecinado en la realización de una obra que oculta durante una década, y que decide finalmente mostrar, hallando en sí los que lo ven, un lienzo lleno de nadería. Después de esto, Frenhofer recupera la cordura y quema su trabajo y muere, expiando su pecado. Otros, los que mantienen la distancia de seguridad y hacen sus puñetitas en círculos sumamente insignificantes -a lo que se puede decir que no son considerables como artistas-, son los que quizás quieran conservar el honor. En fin. Nada cambia, todo es un decorado en movimiento pero siempre, teniendo en cuenta que lo importante es al fin y al cabo es anestesiar cualquier tipo de sentimiento y pensamiento y producir el goce kitsch. La satisfacción de saber que todo sigue igual. Esa es la meta y es El Fin. «Hacer arte es muy sencillo hoy en día». (Kaprow. 2007, p. 15); «Todos los indicios apuntan a su obsolescencia» (Ibíd. 30). Ya Marcel Duchamp anunciaba en 1923, que había colgado los hábitos del arte, en una sociedad en la cual, el arte ya no ocupa el estatus como tal. El arte ha fracasado decía. Baudelaire a su vez, nos habla de la decrepitud del arte.

Se produce por tanto una dicotomía en el mundo de los artistas que va, desde lo íntimo (privado, supuestamente) a lo público, el impulso que los artistas buscan en la publicidad y propagación de su obra, esa especie de trauma por sentirse escuchado en 
un mundo happy few. Leni Riefensthal en Olympia (1938) ya nos mostraba como el premio al esfuerzo permanente significaba pertenecer a una raza superior. Pero hoy, es demasiado alta la capa de deshechos para poder asomar la cabeza por encima del horizonte.

\section{Estado de la cuestión en el sistema de los objetos respecto del arte}

En el siguiente apartado, se pretende establecer una comparativa entre el sistema de los objetos del arte y el sistema de profusión objetual rodea la sociedad de consumo actual. Por otro lado, de la acumulación objetual que vivimos y del coleccionismo, surge el acumulador compulsivo, que en nuestro caso sería aquel sujeto afligido por el síndrome de Diógenes. Ambos comparten una rutina de consumo similar. Por un lado, los artistas, acumuladores de imágenes y resonancias intelectuales pasajeras y por otro, el Diógenes, que consume todo aquello que acapara, «coleccionando» sin lógica, organizándolo en su espacio, instalándolo. Ambos por tanto, sufren del mal de la acumulación desmesurada y de la falta de criterio. Ambos, empecinados en el objeto, inmiscuidos en su rutina y asumiéndolo como proyecto de vida. Algo que explicaremos a continuación y que se debate entre la «comida» y la basura.

De esta manera, el mundo del arte y la vida real se reencuentran en un lugar plagado de objetos. Y toda esta profusión «mecánica» objetual contemporánea cumple una misma premisa, el consumo y su posterior desprecio inmediato, su deglutir y defecación. Si recordamos el cortometraje La isla de la flores (Golulart, N. \& Schmiedt, M., 1989), todo objeto posee una jearquía que en su paso por el mundo y siempre acaba teniendo el mismo desenlace, su muerte. Al final, todo se vuelve abyecto -la etimología de la palabra, Abjicere, significa lanzar lejos, desechar; también, renunciar a toda autoridad, rebajar, ser degradado-.
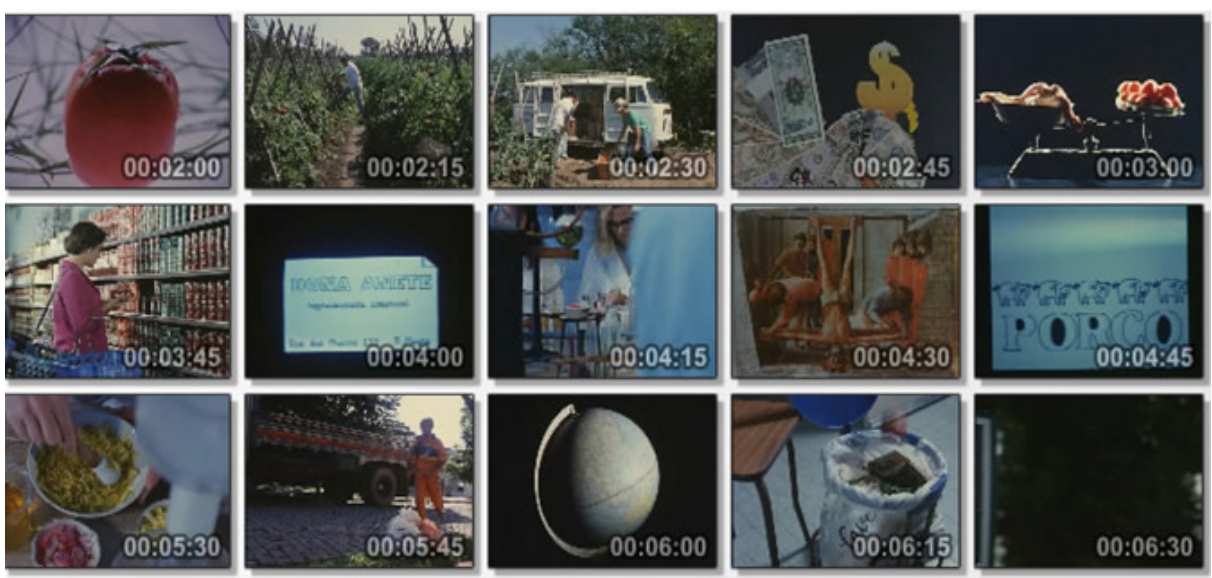

Figura 2. Diferentes fotogramas del cortometraje La Isla de las flores (1989), que muestran el proceso que el tomate sigue desde su producción hasta su consumo. http://22xd.blogspot.com.es/2011/02/laisla-de-la-flores.html 
Intercambios de símbolos como meros productos de relaciones y de capital cultural y del consumo (Bourdieu, 1979), intercambios que dan sentido a nuestras vidas vacías, intercambios que reafirman nuestra identidad buscada. $Y$ de este problema identitario que existe en la sociedad actual, se podría afirmar que el «problema» de las personas reside en la $f e$. Necesidad impertérrita e innegable por aferrarse a la lógica de un mundo desubstancializado y atónico, atónito. Nace así la privacidad y el egoísmo, y entonces «el proyecto de privatización del residuo tiende a volverse el monólogo interior» (Castro, 2011, p. 36). Buscamos la transustanciación en los objetos a la vez que nos hacemos Diógenes del pensamiento. He aquí la paradoja y la afinidad cínica y vertical entre el acumulador de desperdicios y los «ideólogos» que amontonan patchworks de pensamientos basura - de fastfood-. Ambos, contentos por su trabajo, una tarea en loop «sampleado» que se fundamenta en el infinito del nonsense -base fundamental para que el mecanismo del coleccionismo genere sinergia para su propio funcionamiento-.

El arte, se ha vuelto iconoclasta, pero esta postura iconoclasta moderna ya no consiste en crear imágenes, sino en fabricar una profusión de imágenes en las que no haya nada que ver (Baudrillard, 1997, p. 21).

Y en esta confusión/profusión objetual, sucede que se tartamudea el lenguaje hasta perderlo (Auster, 1997) y solo se intercambia como objeto la permutación espacial de las siglas pegadas unas con otras que crean frasecillas ininteligibles, limbo inconexo, lógica extravagante. A veces es mejor no hacer ademán por hablar, lo apropiado es callarse.

Cantidad de dementes, de palabras e imágenes. La estupidez, nunca es ciega o muda. Así que el problema ya no consiste en que la gente se exprese, sino en proporcionar pocos resquicios para la soledad y el silencio en los que quizás acabarán encontrando algo que decir. Las fuerzas represivas no impedirán que la gente se exprese; más bien la forzarán a hacerlo. Qué alivio no tener nada que decir, el derecho a no decir nada, porque sólo entonces existe una posibilidad de enmarcar lo raro, o incluso lo más raro, lo que puede ser digno de decirse. Lo que nos invade en la actualidad no es un bloqueo de la comunicación, sino de las declaraciones sin sentido (G. Deleuze, 1996, p. 247).

La mejor actitud respecto a las palabras es no usarlas. Si pensáis que podéis pasar sin usarlas, no habléis. Lo que debe ser dicho debería serlo siempre de la manera más concisa, lógica y clara posible. Una cantidad sorprendente de personas se ridiculizan hablando sin reflexionar y se desconsideran otra tanto (Tsunetomo, 2005, p. 64).

La acumulación, no importa que sea diogénica o consumista, es el fin. 


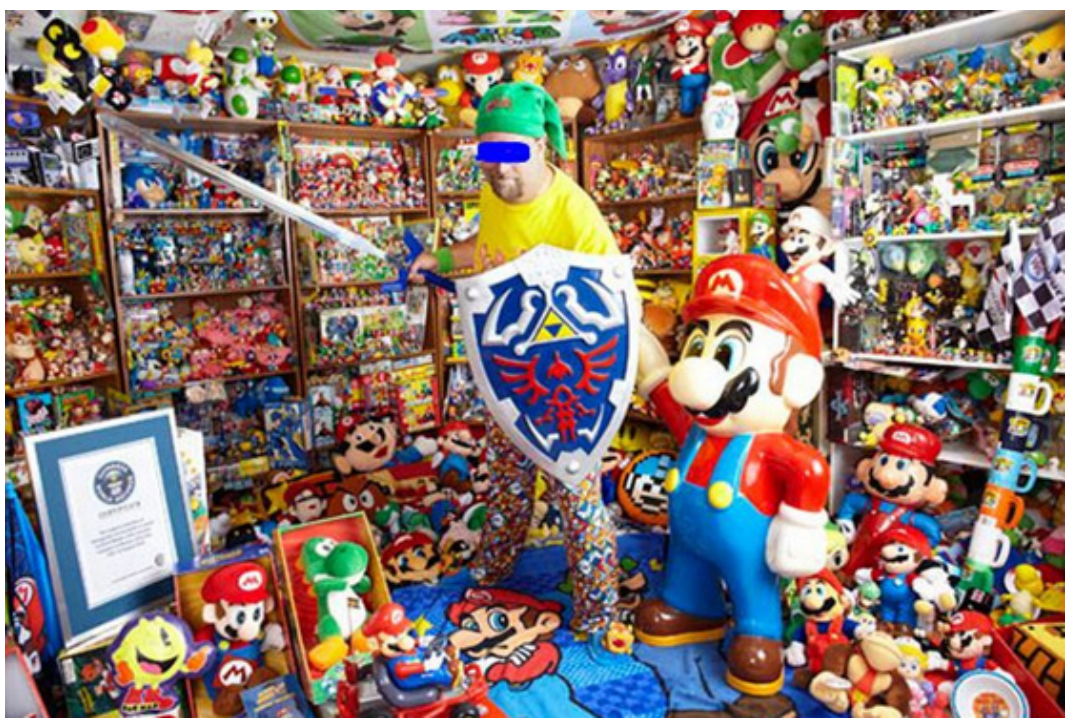

Figura 3. Fotografía que representa una persona afectada por el Síndrome de Diógenes. http://www. cargad.com/index.php/2014/06/27/el-sindrome-de-diogenes/

\section{La patología de la acumulación y la inmundicia}

$$
\text { «...giù nel fosso }
$$

vidi gente attuffata in uno sterco, che da li uman privadi parea mosso. E mentre ch'io là giù con l'occhio cerco,

Vidi un col capo si di merda lordo, Che non parea s'era laico o cherco...»

... abajo en la fosa

vi gentes sumergidas en excrementos que parecian venir de letrinas humanas $Y$ mientras examinaba el fondo con los ojos vi a uno cuya cabeza estaba tan cargada de mierda que no podía verse si era laico o clérigo...

(Aliguieri, D. 1999, p. 13)

Se podría afirmar que en la sociedad contemporánea estamos abocados a vivir en el absurdo, el cual gobierna nuestras vidas. Como Sísifo, subimos la roca y la dejamos caer y así hasta la eternidad -nos «levantamos», nos preparamos, vamos a trabajar,... y volvemos a casa; dejamos caer la piedra continuamente para que al día siguiente se repita el tener que subirla-. Necesitamos de la rutina y del tiempo invertido. Creamos, construimos, acumulamos, desechamos y llenamos nuestro ego de consumo. Somos una gran maquinaria de la producción y la destrucción. Esta dinámica histérica hace que nos comportemos compulsivamente y necesitemos de 
objetos «más tangibles» que nosotros mismos para buscar un anclaje en el mundo pero cuando alargamos la mano para cogerlos ya están transformados en cenizas de sí mismos y esta, es la razón que nos hace sucumbir a la retórica del nunca acabar, a la patología de la eterna esperanza, al coleccionismo de lo inacabable y a la deidad del sinsentido, a seguir haciendo arte.

Por ello, que una sociedad en su proceso vital produce basura y luego, vive encima de ella. Los desperdicios son una consecuencia necesaria de la vida. Necesitamos de los desperdicios para olvidar la muerte, para pensar que nuestra vida se alarga por encima de las Cosas. Para ver la ruina y poder despreciarla. «La mierda es rechazo. Gasto» (Clair, 2007. p. 35). Y así, disfrutar del despilfarro simbólico. «Así el residuo se encuentra sublimado en una ganancia de placer, un enriquecimiento, del cual la obra de arte sería la imagen más noble» (Ibíd. p. 40).

Pero luego, surge la pregunta, ¿qué hacemos con tanta basura? En el caso del arte, ubicar toda producción excremental en templos de basura, sean «casas» sean lugares de la cultura «(...) gran decepción de lo que realmente se esconde detrás» (Baudrillard, 2007, p. 12). En ello radican las necesidades reales del individuo, sus carencias, su ego y estima que ahogan al ser solitario, al artista o al Diógenes. La patología al fin y al cabo, es la misma entre artista y el Diógenes coleccionista-creador de toneladas de basura - o cualquier otro coleccionista- que para no sentir la falta, la soledad, el superar el mal de la propia sociedad, se mimetiza como el vagabundo, el outsider y que recopila fragmentos de una historia que ya no existe, y entonces nos se rodea de desperdicios intelectuales y objetuales. «La obra de un artista no es otra cosa que una idea transustanciada en objeto que sirve para proyectar en ella nuestra personalidad» (Kaprow, 2007, p. 9). Un alguien a quien ya nadie escucha y que retoza en los pensamientos de su compromiso personal. Empujado a la inmundicia.

También la mugre, la suciedad, el mancillamiento, la porquería, el residuo, el lodo, (...), se sitúa tan precisamente en los anaqueles bajo la rúbrica hard crad. Es todo lo que empuja al hombre hacia la orilla negra de la descomposición, de la podredumbre, del bullidero, de la peste» (Clair, 2007, p. 14).

El arte en su «patología-diogénica» tiende en forma a un estado cada vez más «primario», más soez, más imbécil -sin báculo- y al momento prístino en dónde el artista, si fuera honesto, debería recluirse y empezar a pensar como un anacoreta, esto es, «rebajando hacia el suelo, el órgano olfativo otra vez vecino de los órganos genitales» (Ibíd. 38).

Se puede pensar que el señor que hace de «jardinero» y que mueve hojas con esa especie de «aspiradora-invertida-en-función» para reagruparlas, es un romántico ya que al fin y al cabo sus actos pueden ser considerados el culmen del absurdo. Si recordamos el taller realizado en Barcelona en 1995, en el que Victoria Combalia, instó como propuesta del mismo barrer el patio del CCCB y en el que decía: «Limpiar sólo es desplazar la suciedad de un lugar a otro». Irónicamente, «todo gesto, pensamiento y acto puede convertirse en arte según el capricho del mundo» (Kaprow. 2007, p. 19). Es difícil por tanto diferenciar lo que es una acto simple de lo que se cree que podría ser algo más. «Debemos experimentar y reflexionar sobre la significación de las actividades cotidianas sin referirse a ellas como arte» (Kaprow, 2007, p. 121). 
Poner en paralelo el absurdo de nuestras vidas con el absurdo del arte, hace que todo cobre el sentido superlativo de verdadero arte, evidenciando que el arte tal y como se muestra hoy en día sufre del mal enfermo de la tontería.

Esta empresa de filibustero, pillando al azar las ruinas de un mundo en adelante privado de valor y de sentido, allí donde el artista había tenido por misión guardar y mirar la unidad de lo visible, habrá provocado la invasión de la obra por esos «odds and end» que desde ahora serían los papeles de periódico y los rasgones de papel tapiz incorporados al cuadro, esperando, por un desliz insensible pero inevitable, las cerillas, los billetes de metro, las horquillas y los imperdibles, las tapaderas oxidadas de latas en conserva, los trapos sucios y los detritus, en fin, el polvo de chocolate, la ceniza del cigarro y los humores diversos del cuerpo humano (...) todo es bueno para afirmar que la obra ya no es lo que había sido (...) sino la yuxtaposición más o menos aleatoria de sus deshechos, imponiendo el reino tiránico del objeto que lo invade todo, la «realidad rugosa de abrazar», en la ausencia misma de una mano apta para captarla. (Clair. 2007, p., 80).

Si seguimos adentrándonos en el mundo de la inmundicia y por ende del «tufo desagradable» que desprende, si de los restos que se tiran y del, según la historia de nuestra percepción de los olores, caminar hacia desodorar toda fragancia fuerte. Se trata del placer por reprimir el olfato.

Al mismo tiempo, la civilización no deja de ser motivada por la necesidad de un «más goce», que nunca es reducible a la dimensión de lo útil. Está tomada, así, entre la realidad de los excreta y la necesidad de los residuos que vienen de la producción de las riquezas, ellas mismas nacidas de la tríada orden-limpieza-belleza, fruto de nuestra educación, es decir, de la represión de los instintos. (Clair, J. 2007, p. 39).

En definitiva, esterilizar se presenta como una antagonía a nuestra verdadera existencia -bien se pueden observar los incontables intentos a partir del postmodernismo de acercarnos al arte del excremento-. Wim Delvoye, mostró una obra en Lion en el año 2003, llamada Cloaca, se trataba de un artefacto encargado de digerir los restos de las comidas de los restaurantes del propio Lion; y su fin, era crear excrementos similares a los humanos. La única pega con respecto a este parecido era que el resultado excrementicio, no olía, ¿significaba esto desinfectar el residuo hasta el nivel de lo aséptico requerido hoy en día por la esterilidad del arte? Cabe pensar que es peligroso algo que a priori no parece oler y está en mal estado, enfermo. Lo enfermo se encierra en lo más recóndito, tácitamente, sobre nosotros. No interesa que nada Huela en esta sociedad. 


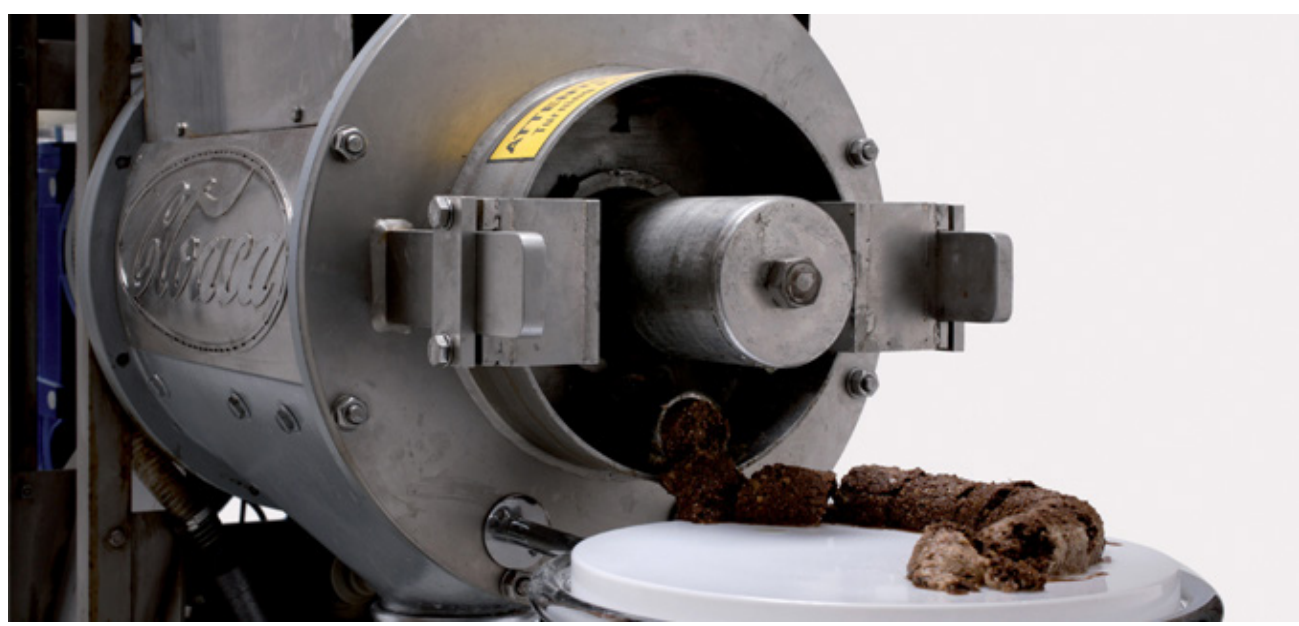

Figura 4. Wim Delvoye. Cloaca. 2007. Recuperado de http://90.146.8.18/en/archives/picture_ausgabe_02_new.asp?iAreaID $=414 \&$ showAreaID $=414 \&$ page $=2 \&$ pagesize $=20 \&$ order $=$ name

«(...) Que los artistas se pongan a coleccionar cabellos, pelos, trozos de uñas, deshechos diversos, en ello puede verse más bien una especie de regreso a la creencia en un mana primitivo» (Clair, 2007, p. 56). Recreamos la fe en lo escatológico. Y se preguntaba Fernando Castro (2012): «ipor qué se ha vuelto común entre los artistas de este fin de siglo usar en sus obras materiales como los cabellos, los pelos, trozos de uñas cortadas, pero además las secreciones y los humores, la sangre, la saliva, los mocos, la orina, el esperma, la sangre, la pus, los excrementos?» (p. 23). El Diógenes acumula -colecciona- los restos de los objetos desechados con el afán de buscar la realidad oculta en los restos; en la «basura» vemos la muerte (Elias, 1987) -es la publicidad la encargada de mostrarnos la juventud eterna y la buena y saludable vida-, aquel que la amontone, se acerca al hedor del símbolo guardado con recelo, a un «mundo pleno». "Cada día, cientos de libros, películas conferencias, seminarios, sesiones de sensibilización, y artículos de prensa reconocen con gravedad nuestra preocupación por la incapacidad de disfrutar libremente cualquier cosa» (Kaprow, 2007, p. 56). Bajo los desechos, la putrefacción, se inmersa uno en la cutícula de la verdad, se pringa uno las manos con lo abyecto y cuanto más se pringa uno y defenestra su dignidad, más humano parece transformarse, más cercano al sentimiento de existencia. 


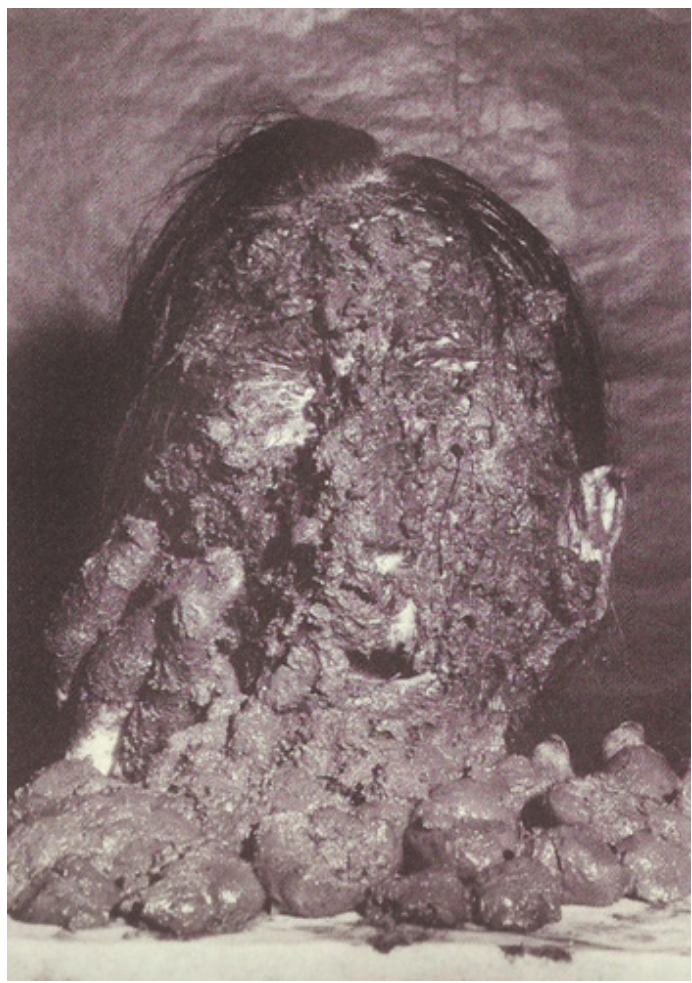

Figura 5. Autorretrato con excrementos (1989) David Nebreda. Recuperado de http://www.revistafiguraciones.com.ar/numeroactual/articulo.php?ida=66\&idn $=4 \& \operatorname{arch}=1$

El artista, se agrupa como una manada de cebras en las que las líneas confunden a los «enemigos»; el Diógenes, se aísla porque ya no le resulta posible entender de grupos, o quizás haya significado, que ha entendido el mundo y escapa a él por miedo a verse reflejado; o por el contrario como diría «La Sociedad», porque no está Adaptado y no ha comprendido la vida. Pero sin duda, ambos comparten un mismo destino, el abandono y el anonimato. La muerte del individuo en un lugar sin escapatoria.

Estancia donde los cuerpos van buscando cada cual su despoblador. Asaz amplio que permita buscar en vano. Asaz estrecho para que toda escapatoria sea vana. (...) Su estancia va a terminar quizá. (Beckett, S. 2005, p. 193).

Sucede que hoy en día ya lo atroz no nos asusta. Comemos frente al televisor mientras vemos como la gente se muere y las catástrofes suceden sin ton ni son. Que nada de todo esto, transformado en arte, signifique ni tan solo llamar la atención. Coprofagia mental. 
Si el horror está banalizado, no es porque veamos demasiadas imágenes de él. No vemos demasiados cuerpos sufriendo en escena, sino que vemos demasiados cuerpos sin nombre, demasiados cuerpos incapaces de devolvernos la mirada que les dirigimos, cuerpos que son el objeto de un habla sin tener ellos mismos la palabra (Ranciere, 2010, p. 100).

\section{Conclusiones}

A continuación, se expone la situación enferma del artista, inmiscuido en sus actos banales y decorativos y de qué forma, el artista debe regresar por aquel camino que hizo perderse. Debe entender lo vacío de su trabajo.

El Diógenes y el artista comparten un destino. Las carencias compresivas por parte de lo que la sociedad «espera de ellos» y de su labor fútil; de ambos, hacer de sí mismo un personaje; un «individuo» que cumple el modus operandi de la «producción» con el fin de aportar un sentido absurdo a sus vidas; viviendo en la creencia de Lo absurdo. En el caso del artista, ni siquiera el absurdo acaba por ser un proyecto de vida pleno y creíble para él y eso, hace que aboque aún más al desastre su postura como «Creador». «(...) El artificio del «arte de verdad» consiste en manipular la censura de la fantasía subyacente de modo que se logre revelar la absoluta falsedad de dicha fantasía» (Zizek, 2001, p. 29). Queda el artista por tanto, recluso en una falacia de mediatinta desleída asumiendo el papel de bufón.

El enfermo y el artista, viven en el mundo de la basura del «imaginario colectivo». Reparten el esfuerzo que ponen en sus trabajos de algo simbólico fracasado de antemano. Es algo ya acabado que solo sirve de estímulo pasajero; y en el caso del artista, de creer sentirse alguien de miras profundas en «teatros mágicos de lobos esteparios» (Hesse, 2012). La diferencia, es que el Diógenes, en su patología descrita y clínica, en su empecinamiento por recoger basura y hacer de ella un tesoro opera en el absurdo de modo «ilógico», concreto y sistemático; el artista, trata de ocultar su sinsentido y su patología no consta como certificada y su «lucidez», enrevesada en ditirambos por su propia creencia de labor funcional raya en lo vacío. «Ahora bien la nulidad es una cualidad que no puede ser reivindicada por cualquiera. La insignificancia -la verdadera, el desafío victorioso al sentido, el despojarse de sentido, el arte de la desaparición del sentido- es una cualidad excepcional de unas cuantas obras raras y que nunca aspiran a ella» (Baudrillard, p. 211-212). De la Basura que produce cree que es un tesoro. Por ello, la simbiosis objetual del valor basuril -que ambos personajes se traen entre manos- se equipara en términos productivos con el enfermo de síndrome de Diógenes. Recopilar -sea basura, sea «el estatus del lugar en la sociedad»- en el mundo del olvido y lo caduco. «El problema de las clases medias que aspiran a progresar en la escala social es que malinterpretan la verdadera causa de su fracaso (...) se siente obligadas a seguir la reglas a rajatabla» (Zizek, 2011, p. 32).

También, el término Artes Plásticas -de hoy en día, traicionando a su etimología parecen hacer alusión a su procedencia del plástico, algún derivado del petróleo más oscuro. « (...) arte, llamado desde ahora ya no «bello» sino «plástico», sumergir de nuevo al individuo en el baño fecal del que se había apartado (...) las producciones de lo que nos es propuesto como «arte» y que provienen de la categoría de lo 
repugnante» (Clair, 2007, p. 37). De material oscuro, pringoso y viscoso de un supuesto «valor añadido». Creación industrial. ¿A cuánto está el barril de crudo hoy? ¿Cuánto petróleo nos queda por sacar? Ya no se puede pensar que el arte posea algo de magia. Parafraseaba Sontag (2005) a Beckett: «Mis sueño de un arte desprovisto de un arte desprovisto de rencor por su indigencia insuperable y demasiado orgulloso para prestarse a la farsa del toma y daca» (p. 21).

(...) la fantasía debe mantenerse «implícita», quedarse al margen del tejido simbólico explícita al que sirve de base y asumir la función de transgresión intrínseca de este. Esta disparidad constitutiva entre el tejido simbólico explícito y su fondo fantasmático resulta evidente en toda obra de arte. La preeminencia del lugar sobre el elemento que se instala en el hace que hasta la obra de arte más armoniosa sea a priori fragmentaria y carezca de algo en relación con el lugar que ocupa: el «engaño» de la obra artística lograda es fruto de la capacidad del artista para convertir esa carencia en una ventaja, para manipular habilidosamente el vacio central y la resonancia que este tiene en los elementos que lo circundan (Zizek, S. 2011, p. 27).

La desolación creativa es el mal que hoy en día azota los pilares de las artes plásticas. «Todas las asunciones estéticas habrán de ser puestas al descubierto sistemáticamente y tiradas a la basura junto con toda la terminología artística recargada de historicismo» (Kaprow, 2007, p. 33). De la inmundicia de lo abyecto y de lo fácil; «jamás la obra de arte ha sido tan cínica y le ha gustado tanto rozar la escatología y la porquería (...) y esta obra habrá sido tan querida por las instituciones. (...) Más inquietante que su fabricación es la recepción de estos objetos» (Clair. 2007 p. 25). Rodeados de montañas de nadería y simplismo que se acumulan organizados en los «prostíbulos del arte». Me temo que no podremos decir, we'll always have Paris (Curtiz, 1942); o quizás tampoco, reducir el arte a cenizas y soplar; como decía Kaprow (2007), «abandonar las artes no es suficiente para superar este obstáculo; la tarea para uno mismo y para los demás, es restaurar la participación en el orden natural a través de la emulación constante de sus rasgos no artísticos» (p. 44).

Des-artistarse sea pues la opción más loable y más honesta para «imitar la vida como antes» y entender que el arte, entre tanta confusión y desperdicio, ya no parece existir en las artes plásticas. En la paradoja del Arte sucede, en un intento por encontrar un referente con sentido, una copia a la vida y a la naturaleza; pero el problema es que la propia vida es un espejo trucado, un vano reflejo de sí misma. Copiamos entonces algo simulado. Luego se podría considerar que lo único que realmente es arte, es la recreación del mundo mismo. Lo único que queda de esencial ahora es comprender su «valor» y sus «nuevos vínculos» con el mundo real. Puede que sea el momento en que se deba reflexionar y tirar la toalla y recordar con la mirada sencilla, lo que fue.

Mancillado pues el arte como Justine (Sade, 2001) en donde el cuerpo yace ahora entre yerbajos con el horizonte-Thousand-Yard-Stare y que recuerda lo vacío en la mirada de la obra «Untitled \#153» de Cindy Sherman; del mismo modo que aparece el cuerpo espatarrado en Étant donnes de Duchamp, sosteniendo la lámpara estoicamente a medio-gas y que dice, queda ya poco que iluminar. Kaprow (2007) nos plantea que «la única opción para redimirnos de la actual situación artística, es reemplazar la identidad del artista» (p. 69) y desnudar la cultura que embarra el mito del arte. Rescatarla de su situación penosa. 

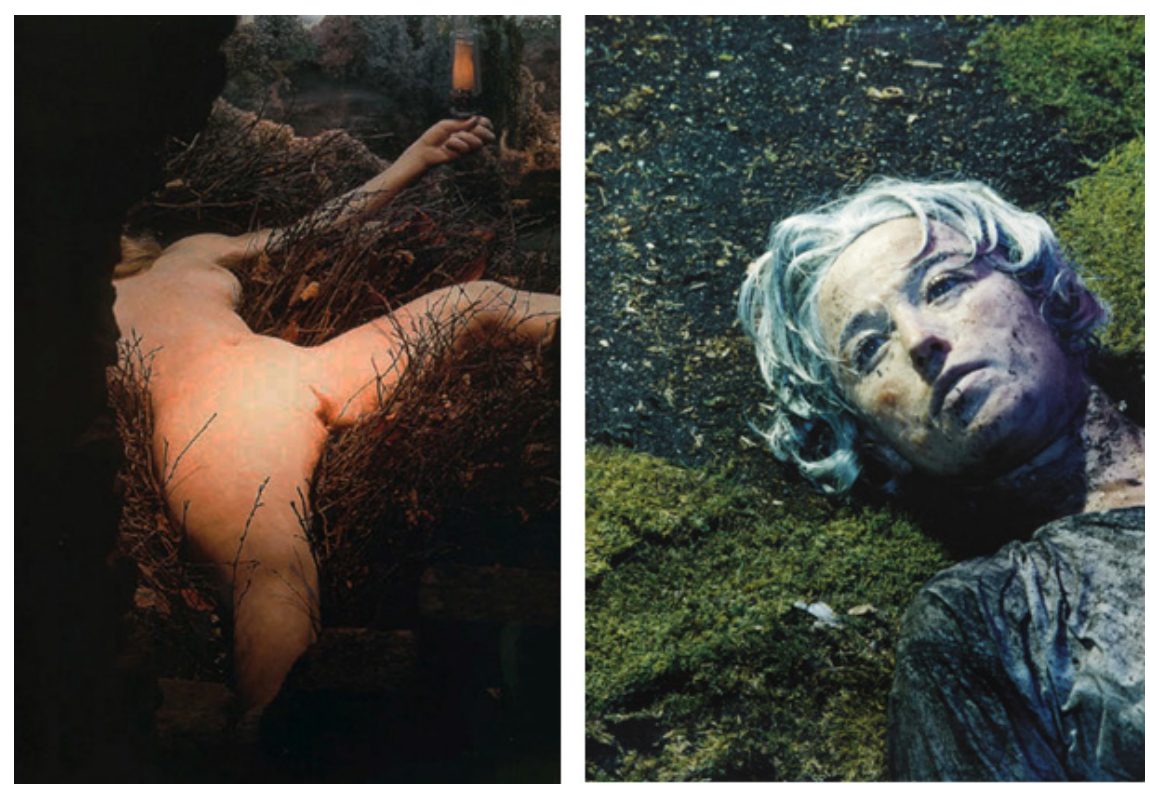

Figura 6. Marcel Duchamp. Étant donnes (1969). Recuperada de http://pedemonte1.wordpress. com/2010/08/16/etant-donnes/

Figura 7. Cindy Sherman. Untitled \#153 (1985). Recuperada de http://www.finishphotography.com/ top-10-expensive-photos-in-the-world/

Todo indica que estamos solos aunque nos rodeemos de Cosas. «El hecho de que las masas sean solitarias a su manera no concede al artista un público o un papel político dado que las masas no quieren que se les recuerde la profundidad de su infelicidad, y que no pueden solucionarla» (Kaprow, 2007, p. 67). Somos, como decía Ulrich Beck (2003), «vagabundos de moral» (p. 41) en un futuro incierto. La soledad es la muerte; en la basura vemos la muerte, en el vagabundo sucio y despreciado está la muerte (Elías, 1987); en una realidad que no debe ser vista y que tiende a lo esterilizado. Vagabundeamos sin norte sobre un suelo sin mácula.

(...) no se sabe cuánto tiempo quedará donde está ahora ni es él quien decide por la general la duración de su estancia. Él elige sus objetivos según va avanzando y según éstos se le van presentando en las señales del camino o de la carretera. Pero ni siquiera así sabe a ciencia cierta si va a descansar en la siguiente etapa, ni cuánto tiempo va a durar. Lo que lo empuja es el desengaño con el último lugar en que paró, y la esperanza, siempre viva, de que el siguiente lugar, aún por visitar, o tal vez el que venga después, esté libre de defectos que han afeado a los ya visitados. (Bauman, Z, 2007 p. 17).

El que gobierne el absurdo, será el que se acerque a cierta verdad. Buscar la esencia de la vida para reencontrar el arte. Acercarnos a lo mundano para recuperar la soberbia y lo sublime. Bajar del cielo y pisar la tierra será lo empíricamente romántico que determinará que el arte, quizás pueda ser salvado. Aquel que verdaderamente ame el arte, se alejará de todo aquello que pueda ser llamado por antonomasia: Arte. 


\section{Referencias}

Aliguieri, D. (1999). La divina comedia. Madrid: Unidad Editorial.

Auster, P. (1997). Ciudad de Cristal. Barcelona: Anagrama.

Balzac, H. de (2011). La obra maestra desconocida. Palma: José J. De Olañeta.

Baudrillard, J. (1969). El sistema de los Objetos. México: Siglo XXI.

Baudrillard. J. (1997) La ilusión y la desilusión estéticas. Caracas: Monte Ávila.

Bauman, Z. (2007). Sobre la educación en un mundo líquido. Barcelona: Gedisa.

Beck, U. \& Beck-Gersheim, E. (2002). La individualización. El individualismo institucionalizado y sus consecuencias sociales y politicas. Barcelona: Paidós/ Estado y Sociedad.

Beckett, S. (2005). Relatos. Barcelona: Tusquets.

Bourdieu, P. (1979). Los tres estados del capital cultural. Barcelona: Anagrama.

Bourdieu, P. (1995). Las reglas del arte. Barcelona: Anagrama.

Castro, F. (2012). Contra el Bienalismo. Crónicas fragmentarias del extraño mapa artístico actual. Madrid: Akal.

Clair, J. (2007). De immundo. Madrid: Arena Libros.

Elias, N. (1987). La soledad de los moribundos. Méjico: Fondo de Cultura Económica.

Golulart, N. \& Schmiedt, M. (Productoras), \& Futrado, J. (1989). Ilha das flores [DVD]. Brasil: Golulart, N. \& Schmiedt, M.

Hesse, H. (2012). El lobo estepario. Madrid: Alianza Libros de bolsillo.

Kaprow, A. (2007). La educación del des-artista. Madrid: Árdora Ediciones.

Otero, E. (2008). Joseph Beuys: Cada hombre es un artista. Peatom. Recuperado de http://www.peatom.info/3y3/artes/16289/cada-hombre-es-un-artista/

Panero, L. M. (2002). Los señores del alma (Poemas del manicomio del Dr. Rafael Inglot). Madrid: Valdemar.

Ranciere, J. (2010). El espectador emancipado. Castellón: Ellago.

Riefensthail, L (Productora), \& Riefensthail, L (directora). (1938). Olympia [DVD]. Alemania: Olimplia-film.

Sade, M. de (2001). Justina o los infortunios de la virtud. Madrid: Cátedra.

Smithson, R. (1993). Sedimentación de la mente. Proyectos de tierra, en Robert Smithson, El paisaje Entrópico. Una retrospectiva 1960-1973. IVAM. Valencia: IVAM.

Sontag, S. (2005). Estilos Radicales. Madrid: Suma de Letras. Madrid.

Tecnozono. (2012). ¿Qué es la basura?. Recuperado de http://www.tecnozono.com/ basura.htm

Tsunetomo, Y. (2005). Hagakure, El camino del Samurai. Madrid: Arkano Books.

Vozmediano, E. (2009). Arte en la edad del pavo. Revista Occidente. Recuperado de http://elena.vozmediano.info/arte-en-la-edad-del-pavo/

Wallis, H. B. (Productor), \& Curtiz, M (Director). (1942). Casablanca [DVD]. Estados Unidos: Warner Bros. Pictures.

Zizek, S. (2011). El acoso de las fantasías. Madrid: Akal. 